\title{
TRIBUTE TO NIEVES LÓPEZ MARTÍNEZ
}

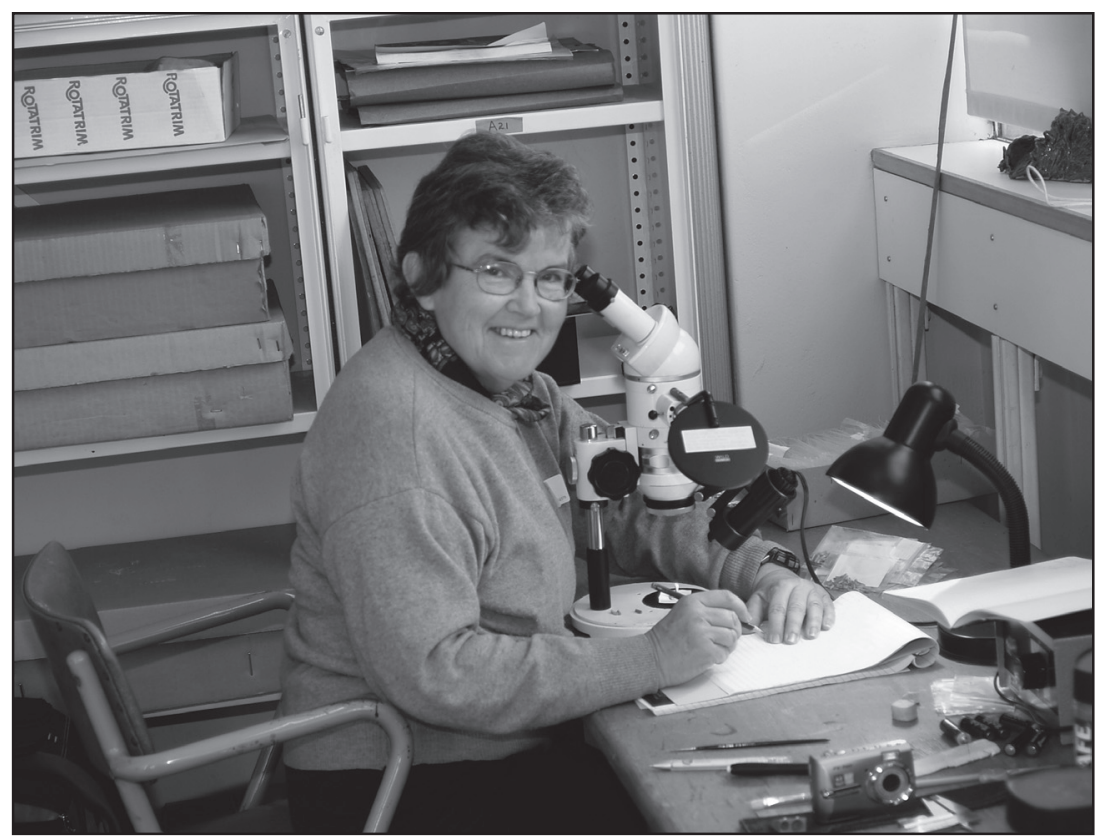

Foto: Cortesía de Jorge Morales.

Guest co-editors

María Ángeles Álvarez Sierra

Dept. Paleontología, Univ. Complutense Madrid Instituto de Geosciencias (UCM, CSIC)

Humberto Astibia Ayerra

Dept. Estratigrafía y Paleontología, Univ. País Vasco

Manuel Hernández Fernández

Dept. Paleontología, Univ. Complutense Madrid Instituto de Geosciencias (UCM, CSIC)

Salvador Moyà Solà

Institut Català de Paleontologia, Miquel Crusafont 


\section{NIEVES LÓPEZ MARTÍNEZ, PASSION FOR SCIENCE}

Nieves was born in Burgos on February $5^{\text {th }}, 1949$ and passed away, much too soon, on December $15^{\text {th }}$, 2010. At a very early age, she was seen to have extraordinary intellectual skills and a particular interest in Natural Sciences and drawing. She studied at Madrid's Complutense University (UCM) from which she graduated with a degree in Biological Science in 1970; there she met Professor Emiliano Aguirre and, like many other students, was captivated by his fascinating personality. So, when he suggested starting a research project on lagomorphs (pikas, rabbits and hares) from the Spanish fossil record, Nieves threw herself into the job with her characteristic energy and enthusiasm. With the passing of the years she became a renowned specialist, recognised for her work in this group of small mammals, which is a particularly complex and difficult one.

At a time (1971-1973) when very few scientists travelled abroad, Nieves obtained a Cooperation Grant from the French Government to do her PhD Thesis under the supervision of Dr. Thaler at Montpellier University. In 1972, she presented the Diplôme d'Études Aproffondus (DEA) and in 1974 she defended her first PhD Thesis, Docteur Specialité (Paléontologie). In the years she spent in France she came to know numerous colleagues with whom she maintained close professional and personal ties (Michaux, VianeyLiaud, Aguilar, Mein, Hugueney, Godinot, Marandat, Sigé, among others). In Montpellier, she also had the opportunity to attend several courses on Geology, a discipline she was always interested in, and she even attended a field-trip in the Alps with the prestigious Professor Mattauer. On her return to Spain, having obtained a PFPI pre-doctoral grant (1974-1977) at the "Lucas Mallada" Institute, belonging to the CSIC (higher council for scientific research), in 1976 she became a Doctor of Science (Biology Section) at the UCM's Faculty of Biological Sciences and, in 1977 she obtained the title of Doctor in Science (Geology Section) at the Faculty of Geological Sciences of the UCM. She won the Extraordinary Doctorate Award for the latter Thesis.

Her university teaching career began in 1978 as an Interim Associate Teacher at Madrid's Autónoma University (UAM). She remained at this university until 1982, always maintaining a very special relationship with the institution and with her colleagues there. In 1982 she went back to the Complutense University, where she spent most of her scientific career, as a Numerary Associate Professor and in 1983 she obtained her Cathedra in Palaeontology. In her 30 years plus in teaching, she taught numerous topics but where she clearly made her mark upon all her students was undoubtedly in the courses of Vertebrate Palaeontology and Palaeobiogeography. She was an excellent teacher and the driving force of her professional life was to a great degree her relationship with her students. She was innovative in her teaching, making use of the new technologies (virtual campus, web pages, blogs, etc.) to gain students' attention and interest. She promoted intensive participation by her students in the development of the subjects she taught and she participated in several projects on innovation in teaching, which she used to create highly original and diverse didactic material. In collaboration with D. Jaime Truyols she wrote a book on the general aspects of Palaeontology, which is commonly used by teachers and students, and she coordinated the extraordinary "Field Guide to Spanish Fossils". For years she led the palaeontology excavation project on Miocene vertebrate fossils in Somosaguas, which constituted an innovative and unique teaching experience within the field of Palaeontology in Spain. She promoted and was the essence of the Interuniversity Doctorate on Palaeontology, with a quality mention, which involved three of Madrid's public universities (UCM, UAM and UAH). She directed over twenty dissertations and advanced studies diplomas (DEAs), as well as numerous PhD Theses addressing very different themes: small mammals (Álvarez-Sierra, 1986; Sevilla, 1986; García Moreno, 1987; De Paz García-Guerrero, 1995; Angelone, 2005), Palaeozoic vertebrates (Soler, 1993), Tertiary teleosts (De la Peña, 1993), pteropod dinosaurs (Torices, 2007), geochemistry (Domingo, 2008) and even techtonics (Élez, 2008).

She excelled in her research and was one of the pioneers in directing research projects of the National Plan; she directed numerous field campaigns and excavations in the continental basins of the Iberian Peninsula and participated in the stimulating and arduous campaigns in the Republic of Chad together with her French colleagues under the direction of Dr. Brunet (Poitiers University). Her Curriculum Vitae is impressive, not only because of the quality and quantity of her production, but also due to the diversity thereof, which can only be understood if one was familiar with her inquisitive nature and vocation for research. She published around 200 scientific papers and books and participated in over 100 congresses and science meetings. We 
cannot enumerate all her works, but we should say that she stood out in all the fields of Palaeontology: Taxonomy, Systematics, Taphonomy, Evolution, Palaeobiogeography, Biochronology and Biostratigraphy. In many cases she pioneered the introduction of certain themes in Spain such as, for instance, the study of the record and evolution of small mammals, in general and especially in the Cretaceous/Palaeocene, Oligocene, Miocene and Quaternary. Nieves introduced the methodology of cladistic systematics into the world of extinct micromammals and was one of the first Spanish researchers to use these in biostratigraphic and biochronological studies in continental environments. Lastly, she was a forerunner in palaeontological studies of area biogeography with small mammals. Since 2004 she had been directing the UCM's Research Group "Geological Record of critical periods: palaeoclimatic and palaeoenvironmental factors" and throughout her professional career, she collaborated with countless Spanish and foreign colleagues with whom she cultivated intense, long-lasting and fruitful professional and personal relationships.

Her intense activity in teaching and research was perfectly complemented by her interest in disseminating science. Beyond her teaching work within the Somosaguas Palaeontology Project, she also participated actively in numerous dissemination actions associated with this project involving the general public; from open days during the excavation campaign, exhibitions and science weeks to the development of interactive materials and finally, the incorporation of the 2.0 web environment. In 2006 she became one of the first professors in the scope of Earth Sciences to create a scientific blog in our country. Indeed, she participated actively in four: Teaching in Palaeontology of Vertebrates (http://paleovertebrata.blogspot.com. es/), Humans and Animals (http://humanos-y-animales.blogspot.com.es/), GeoPaleoBiological Research in Somosaguas (http://investigacionensomosaguas.blogspot.com.es/) and Beyond Somosaguas (http://masalla-de-somosaguas.blogspot.com.es/). This placed her as leader of the select group of the first university teachers to integrate the new technologies of the information into their day-to-day work involving public dissemination of science. Undoubtedly, her example served to encourage many others to follow in her footsteps, making Spain's "palaeoblogosphere" a leader within the international scope.

Nieves had a strong charming personality. She was enthusiastic, curious, active, fascinating. She was the synonym of bravery, rigorousness, excellence, talent and hard work. Sadly, she left us while she still had many ideas, projects and research lines to develop. Her students, colleagues and friends encounter her everywhere, in every tooth we measure and study, in each cladogram we see, in every new (or old) offprint we read, in every landscape we glimpse and in all aspects related with Palaeontology.

The diversity of interests of Nieves López Martínez can be seen in this volume of the revised Spanish Journal of Palaeontology, the first of a series to be dedicated to our dear teacher, colleague and friend. Together, these commemorative issues will contain many of the works presented in the workshop in homage to Nieves held on March $2^{\text {nd }}-4^{\text {th }} 2012$ in Miraflores de la Sierra. This event, under the name "All that we left to tell you", organised by Ángela Delgado Buscalioni, Manuel Hernández Fernández, Ana Rosa Gómez Cano, Adriana Oliver Pérez, Enrique Cantero Hernández, Blanca A. García Yelo, Verónica Hernández Ballarín and Omid Fesharaki Tabatabaei, brought together over a hundred palaeontologists, geologists and friends from all over Europe.

To end with, we wish to thank the authors of the manuscripts presented for their contribution, and to the reviewers for their cooperation during the months of preparation of this tribute. All of us who have participated in creating this first issue, with great affection, to the memory of Nieves López Martínez would want her to appreciate the articles and the work done. Because this would mean that we had done a serious and rigorous job.

Farewell our dear teacher.

Guest co-editors

Marián Álvarez-Sierra, Humberto Astibia Ayerra, Manuel Hernández Fernández, and Salvador Moyà Solà 